\title{
Atlantic Universities Geological Conference \\ 1999
}

October 14-16, 1999

ABSTRACTS

\section{Conference hosted by:}

\author{
Alexander Murray Geology Club \\ Memorial University of Newfoundland \\ St. John's, Newfoundland
}

Again this year, abstracts from the annual Atlantic Universities Geological Conference (AUGC) are published in Atlantic Geology. This provides a permanent record of the abstracts, and also focuses attention on the excellent quality of these presentations and the interesting and varied geoscience that they cover.

The Editors 


\title{
Stratigraphic correlation of a Late Carboniferous interval in the Stellarton Basin, Nova Scotia, and possible evidence for tidal influence
}

\author{
Tanya Costain \\ Department of Earth Sciences, Dalhousie University, Halifax, NS B5H 4JI
}

The Stellarton Basin is located in central Nova Scotia between the Cobequid and Antigonish Highlands. The $6 \mathrm{~km}$ by $18 \mathrm{~km}$ basin developed as a rhomb graben caused by dextral movement along its two bounding faults, the Cobequid Fault to the north and the Hollow Fault to the south. Deposition began during the Westphalian B and continued until late in the Westphalian.

The Stellarton Formation is composed of approximately $2600 \mathrm{~m}$ of Late Carboniferous fluvial, deltaic, and lacustrine strata. This study concentrates on an interval within the Coal Brook Member of the Stellarton Formation. The interval consists of between 10 and $20 \mathrm{~m}$ of strata organized into coarsening upward sequences mapped from drill core and outcrop. A typical sequence begins with a flooding oilshale unit that grades into mudrock (some of which is rhythmically layered), and fine-grained sandstone, the latter units representing regression and delta growth. Coarsening upward sequences grade laterally into predominantly mudrock sequences, indicating increasing distance from the sediment source.

Research carried out as part of this study has found possible paired mud drapes within some of the rhythmically layered mudrock of the Coal Brook Member. This evidence is the first to suggest tidal influence during deposition of the Stellarton Formation, as these structures are characteristic of tidal influence in some modern settings. The possibility of tidal influence is surprising because of the lack of marine fossils and the low-sulfur content of the coals in the Stellarton Basin. If tidal influence is confirmed it would indicate a possible periodic estuarine presence in the system.

\section{A survey of a magnetic anomaly in foreland basin sediments of the western Newfoundland Appalachians}

\author{
Jerry C. DeWolfe \\ Department of Geology, Saint Mary's University, Halifax, NS B3H 3C3
}

A pair of magnetic anomalies, known as the "OddTwins", was first discovered off the coast of Western Newfoundland in 1968. Recent swath bathymetry and magnetic mapping north of Port au Port Peninsula allow this anomaly to be traced near the coast, within $7 \mathrm{~km}$ along strike from outcrop of the Late Ordovician Long Point Group.

A magnetic survey was carried out on land using a portable proton magnetometer. Six hundred and eleven readings were taken on 22 traverses. Fifteen traverses intersected a conspicuous, linear feature trending NE-SW that projects toward the eastern offshore anomaly. A second anomaly, approximately $1 \mathrm{~km}$ to the northwest, was intersected by five traverses. Projected, it is aligned with the western offshore anomaly. A regional-residual separation for the data was carried out using values calculated from an industry airborne magnetic survey (now in the public domain), and data were corrected using IGRF95 values.

The eastern anomaly occurs close to the base of the Misty Point Formation of the Late Ordovician Long Pond Group. The western anomaly occurs within the Misty Point Formation. Both anomalies strike NE, and are asymmetric, with steep gradients on the southeastern side. These observations are consistent with an origin in the Long Pond Group observed in outcrop. Toward the southwest, the asymmetry reverses. This effect probably results from overturning of the Long Pond Group in the footwall of the Acadian Round Head Thrust.

The Odd-Twins anomaly provides an essential stratigraphic tie between the on-land succession and an extensive offshore seismic data-set resulting from petroleum exploration.

\section{The origin and significance of zabuyelite $\left(\mathrm{Li}_{2} \mathrm{CO}_{3}\right)$-bearing fluid inclusions in spodumene from granitic pegmatites}

\author{
S.L. Gray \\ Department of Geology, St. Francis Xavier University, Antigonish, NS B2G 2W5
}

Liquid-vapour-solid phase inclusions in spodumene $\left(\mathrm{LiAIS}_{2} \mathrm{O}_{6}\right)$ have been interpreted to be the products of a hydrous silicate melt that was entrapped during crystallization. However, recent laser Raman spectroscopic analyses indicate that lithium carbonate is a major component of the entrapped fluid, as shown by the presence of the mineral zabuyelite $\left(\mathrm{Li}_{2} \mathrm{CO}_{3}\right)$ in the inclusions. The high carbonate content of these inclusions is inconsistent with previous estimates of fluid composition and is typical of fluid inclusions trapped during a lower temperature hydrothermal stage in granitic rocks. In this study, the bulk composition and origin of fluid inclusions in spodumene from the Tranco pegmatite, Manitoba, were reevaluated on the basis of (1) new petrographic data, (2) laser Raman spectroscopic analyses of solid phases in 300 separate fluid inclusions, and (3) thermodynamic analysis of the stability of the inclusion constituents in the system $\mathrm{Li}_{2} \mathrm{O}$ - 
$\mathrm{Al}_{2} \mathrm{O}_{3}-\mathrm{SiO}_{2}-\mathrm{H}_{2} \mathrm{O}-\mathrm{CO}_{2}$.

Petrographic evidence, such as the occurrence of fluid inclusions in healed microfractures that cross cut spodumene laths, indicate a secondary or pseudo-secondary origin. Of the 300 fluid inclusions examined, zabuyelite and quartz are the most common and widespread mineral constituents. Other solids, which were found less frequently, include cookeite, and three unidentified minerals. Thermodynamic analyses of the phases identified in these fluid inclusions were performed using the computer program PTAX (Berman et al., 1988). The analyses show that the following reactions:

$$
\begin{gathered}
5 \text { spodumene }+\mathrm{H}_{2} \mathrm{O}+2 \underset{\mathrm{CO}_{2}=\text { zabuyelite }+7 \text { quartz }+}{\text { cookeite }} \\
2 \text { spodumene }+\mathrm{K} \text {-feldspar }+\mathrm{H}_{2} \mathrm{O}+\mathrm{CO}_{2}=\text { zabuyelite }+ \\
\text { muscovite }+4 \text { quartz }
\end{gathered}
$$

can occur at the $\mathrm{P}$ and $\mathrm{T}$ trapping conditions for secondary fluid inclusions in the associated quartz.

Rather than the precipitation of daughter minerals from a trapped hydrous silicate melt, the results of this study suggest that a late aqueous carbonic fluid reacted with spodumene to give rise to the observed inclusion assemblage. An alternate mechanism for the precipitation of zabuyelite and quartz involves boiling of the hydrothermal fluids and the partial loss of $\mathrm{CO}_{2}$ from the system. Such boiling could result in simultaneous precipitation of zabuyelite and quartz and subsequent closure of fluid inclusions by healing of the microfractures.

\title{
A reconnaissance paleomagnetic study of the Bull Arm Formation of the western Avalon Peninsula, Newfoundland
}

\author{
Sherri Jordan \\ Department of Earth Sciences, Memorial University, St. John's, NF AlB $3 X 5$
}

Although much evidence supports rapid Precambrian migration of Laurentia from near the south pole to the equator, great debate still continues concerning the position of Avalonia during the late Proterozoic-early Paleozoic. In an attempt to constrain the position of Avalonia, the bimodal Bull Arm Formation of the western Avalon Peninsula was chosen for paleomagnetic study because of its suspected age ( $\sim 570$ $550 \mathrm{Ma}$ ) and relatively unaltered condition.

The paleomagnetic results from the Bull Arm Formation indicate that 4 out of 7 sites displayed a stable characteristic remanence held by hematite which was isolated during stepwise alternating field demagnetization. Although a conglomerate test was inconclusive, a positive fold test indicates that this characteristic remanence predates folding and is most likely primary. The tilt-corrected site-mean characteristic remanence has a declination of $62^{\circ}$ and an inclination of $-40^{\circ}\left(\mathrm{k}=5.8, \alpha_{95}=18.5\right)$ yielding a paleopole at $3.8^{\circ} \mathrm{S}, 78^{\circ} \mathrm{E}\left(\mathrm{dp}=13.4^{\circ}, \mathrm{dm}=22.2^{\circ}\right)$ for West Avalonia. The corresponding paleolatitude for the Avalon Peninsula is $23^{\circ} \mathrm{S}$ $\pm 13^{\circ}$. The large error associated with the paleolatitude as well as the lack of a precise radiometric date for the Bull Arm Formation limit the extent to which these results can be applied to paleogeography. However, doubling the number of sites studied should reduce the error to an acceptable level and the presence of zircon in some felsic flows should allow precise $\mathrm{U}-\mathrm{Pb}$ dating in the future.

\section{The Maritimes and Northeast Pipeline Project: geological applications and environmental impacts}

\author{
Kirsten J. McLaughlin \\ .. Department of Geology, University of New Brunswick, Fredericton, NB E3B $5 A 3$
}

The Maritimes and Northeast Pipeline (M\&NP) was constructed as a distribution network for Sable Offshore Energy natural gas to consumers in Nova Scotia, New Brunswick, and the United States, and is scheduled to be in service by November 1, 1999, during peak consumer interest. The mainline extends from Goldboro, Nova Scotia. to Boston, Massachusetts. On completion, projected laterals in New Brunswick will transport gas to Saint John, Belledune, and Edmunston. A range of geological applications was used in the preliminary studies of the proposed Right of Way (RoW), including petrology, geochemistry, and geophysics.

The entire length of the RoW was probed for rock identification and overburden depth. These samples were also analyzed in areas where the bedrock geology indicated the possibility of generating acid-rock drainage (ARD). High acid potential units include the Digdeguash and Kendall Mountain formations, outcropping in southwestern New Brunswick, and the Sunbury Formation in eastern central New Brunswick.

The Digdeguash Formation is composed of grey shale, siltstone, and greywacke. Diagenetic pyrite in the shale is the primary acid generator; the shale comprises over $40 \%$ of the formation. The Kendall Mountain Formation is composed of quartz arenite and pyrite-bearing black shale. Although the shale make up less of the Kendall Mountain Formation than the Digdeguash Formation, the concentration of pyrite is higher in the former unit, causing equal concern (KP 520 to $536.5 \mathrm{~km}$ ). The Sunbury Formation (KP 393 to $425 \mathrm{~km}$ ) is coarse-grained quartz arenite sandstone and polymictic conglomerate, with elevated concentrations of pyrite. Sections of the RoW in the formations above have $>0.3 \%$ sulphur and a 
$\mathrm{Np}: \mathrm{Ap}>3$. In addition to the high ARD potential targets above, other intervals of the RoW were also monitored for ARD during construction.

The pipeline construction schedule was planned in consideration of the substantial environmental protection plan (EPP) put forth by M\&NP. The network of water courses in New Brunswick require conservation in the wake of forestry and construction projects in their proximity. Sediment loading and habitat destruction in fish bearing (especially salmonid) streams can cause damage to fish, invertebrates, and other ecologically valuable organic populations. Over 180 water courses were crossed in the Canadian section of the pipeline, by either the dry (dam \& pump) method or the wet (in-stream) method. Construction techniques and proactive measures (silt fences, diversion berms, and dam and pump) were implemented to ensure minimal disruption to water courses and wetlands.

\title{
An examination of the hydrological, geophysical, geological, and geochemical properties of aquifers at the Morton Centre for Environmental Study, Heckmans Island, Nova Scotia
}

\author{
Peter Morse \\ Department of Geology, Acadia University, Wolfville, NS BOP $1 X 0$
}

A comprehensive investigation designed to examine and determine the quality of the ground water resources at the Morton Centre for Environmental Education, Heckmans Island, Lunenburg, Nova Scotia, was undertaken during 1998 and 1999.

Results from seismic refraction and soil and exposed bluff cross-sections allow identification of the overburden stratigraphy. Positive bedrock topography in the drumlin underlying the Morton Centre is overlain by the Hartland Till, Clayey Phase Lawrencetown Till, and Sandy Phase Lawrencetown Till, respectively. Water well levels consistent with geophysical observations indicate that a shallow perched water table occurs within the Clayey Phase of the Lawrencetown Till, and an underlying piezometric surface occurs $1.4 \mathrm{~m}$ above sea level in fractured bedrock.

Complementary hydrological investigation provides estimates of hydraulic conductivity of the overburden diamictons, plus constraints on fracture-controlled permeability of bedrock. Local structural mapping identified axial-planar cleavage, bedding, and extension joint orientations responsible for this permeability.

Geochemical concentrations in ground water from five wells indicate that, except for turbidity in the dug wells, the water is acceptable for drinking purposes.

In combination, results indicate that a fresh/saline water diffusion layer occurs $40.8 \mathrm{~m}$ below the bottom of the drilled well supplying water to the Morton Centre. Increased use of the property in the future will raise groundwater extraction rates, possibly causing influx of sea water into this well. Further studies are required to determine how much additional water use would be required to cause saltwater influx, and to provide strategies for avoiding this possibility in the future.

\section{Structural analysis and cooling history of the northern Shuswap Metamorphic Core Complex using the ${ }^{40} \mathrm{Ar} /{ }^{39} \mathrm{Ar}$ method}

\author{
lain Pirie \\ Department of Earth Sciences, Dalhousie University, Halifax, NS B3H $3 J 5$
}

The Shuswap metamorphic core complex (MCC) of the Omineca Crystalline belt is located in the hinterland of the North America Cordillera. The study area, focused on the illdefined northern tip of the Shuswap MCC near Valemont, British Columbia, consists of three lithotectonic units. The North Thompson-Albreda fault juxtaposes two amphibolitefacies lithotectonic units, the Mica Creek succession to the west and the exhumed Malton Gneiss of the Shuswap MCC. Several high-angle normal faults trending north-south dissect the high-grade unit. The Southern Rocky Mountain Trench truncates the North Thompson-Albreda fault and juxtaposes the Omineca Crystalline Belt to low-grade metasedimentary rocks of the Rocky Mountain Fold and Thrust Belt to the east. The exact nature of fault motion within the Southern Rocky Mountain Trench is not fully understood. Identification of the relative motion between the various lithotectonic units is grounded on structural analysis based on field mapping. Microstructural analysis is used to document the relative motion between the various units and ${ }^{40} \mathrm{Ar} /{ }^{39} \mathrm{Ar}$ dating of amphibole and muscovite is employed to constrain their cooling history. In particular, the ${ }^{40} \mathrm{Ar} /{ }^{39} \mathrm{Ar}$ data are implemented to clarify discrepancies in the cooling ages identified in the previous studies. Structural mapping and analysis combined with ${ }^{40} \mathrm{Ar}{ }^{39} \mathrm{Ar}$ thermochronology are implemented in order to constrain the exhumation history of the northern tip of the Shuswap MCC. This information is used to supplement pre-existing structural and isotopic data for the region and to aid in defining a model of exhumation for the Shuswap MCC. 


\title{
"Soapy rock" in $18^{\text {th }}$ Century ceramic pastes: talc or serpentine?
}

\author{
Walta-Anne Rainey \\ Department of Geology, Saint Mary's University, Halifax, NS B3H 2 C9
}

Some early $\left(18^{\text {th }}\right.$ century) British porcelains have magnesian compositions reflecting the use of Cornish "soapy rock" in their pastes. As a consequence, the fired wares contain enstatite and/or diopside. Traditionally, the "soapy rock" has been interpreted to be steatite, a talc-rich rock derived from the hydration of peridotite from the Lizard peninsula. There is no doubt that narrow veins of steatite occur in the serpentine-rich rocks in this area. However, contemporary accounts record the fact that workmen had trouble separating the two rocks, to the point that "... they ... received instruction lately not to be so exact in ... separating it." Furthermore, Josiah Wedgewood noted that he examined this rock, collectively referred to as "soap rock," "from its softest state to a state of induration sufficiently hard for making the roads with ...." It therefore seems plausible that serpentine as well as talc were included in magnesian pastes. Indeed, there is evidence that some potters do not distinguish these minerals even today - analysis of "talc" purchased from a pottery supply company proved to be mostly antigorite. In order to test the likelihood that serpentine was included in these wares, controlled kiln-firing experiments were performed on pastes mixed according to recipes calculated from the composition of archaeological potsherds from $18^{\text {th }}$ century British porcelain factories, as well as an ideal (stoichiometric) quartz-calcite-"talc" mixed in proportions required to form only diopside. Preliminary results show that, during firing of a quartz-calcite-serpentine (talc, diopside/endiopside) paste at $1000^{\circ} \mathrm{C}$, rims of akermanite $\left(\mathrm{Ca}_{2} \mathrm{MgSi}_{2} \mathrm{O}_{7}\right)$ start to form on calcite after approximately 40 minutes, and subsequently on the other phases. Forthcoming firing experiments will be conducted to determine if the akermanite breaks down to yield pyroxene(s) at temperatures approaching the vitrification point $\left(\mathrm{T} \sim 1250^{\circ} \mathrm{C}\right)$ of this material.

\section{Petrology and mineral chemistry of the Mount Brome Alkali Complex, Quebec}

\author{
Sean Timpa \\ Department of Geology, Acadia University, Wolfville, NS BOP IXO
}

The Mount Brome Alkali Complex is situated $190 \mathrm{~km}$ east of Montreal, Quebec, and is the largest and most easterly of the Monteregian Hills. The magma that formed the complex was emplaced hypabysally in the St. Lawrence River aulacogen by hot spot activity around $125 \mathrm{Ma}$. The surface exposure of the complex is $56 \mathrm{~km}^{2}$. Mount Brome, after which the complex is named, is located on the northern tip.

The Mount Brome Alkali Complex is composed of gabbro and cogenetic alkali silica-undersaturated and silicaoversaturated rocks. The gabbro unit makes up the southeastern third of the complex and is composed of layered melanocratic and leucocratic rocks. The silica-oversaturated rocks are syenite and biotite monzodiorite. The syenite unit intruded the biotite monzodiorite unit as indicated by brecciation and recrystallization of the biotite monzodiorite along the contact with the syenite. The syenite contains numerous xenoliths of country rock and has a gradational relationship with silica-saturated and silica-undersaturated rocks. The silica-undersaturated rocks are nepheline-bearing syenite, sodalite-nepheline monzodiorite and sodalite- nepheline monzosyenite. The nepheline-bearing syenite is gradational between the syenite and the sodalite-nepheline monzosyenite. The sodalite-nepheline monzosyenite contains up to $40 \%$ nepheline and sodalite and is gradational with the sodalite-nepheline monzodiorite. The sodalite-nepheline monzodiorite contains numerous inclusions of a diorite unit not exposed at the surface.

Chemical analysis with the electron microscope of minerals in the major units has revealed unusual mineral compositions and trends. The gabbro consists of three distinct sub-units: gabbro, alkali gabbro and poikilitic amphibolebearing gabbro. Alkali feldspar compositions vary greatly and include barium-rich alkali feldspar with up to $17 \% \mathrm{BaO}$ in the alkali gabbro. Alkali feldspars commonly display zoning and prominent perthitic or anti-perthitic texture. Plagioclase compositions generally range from andesine to oligoclase with more calcic compositions present in the gabbro. The rocks contain a variety of amphibole, ranging from ferro-actinolite to kaersutite. Titanite, rutile, ilmenite and titaniferous biotite are present in most units.

\section{Forward 4-D seismic modelling of the Hibernia Reservoir}

\author{
Richard Wright \\ Department of Earth Sciences, Memorial University, St. John's, NF AlB $3 X 5$
}

Over the past 2 years, the Hibernia oil field has produced approximately 60 million barrels of oil. Seismic reflection data rely on contrasts in subsurface acoustic impedance (density $\times$ velocity) to image different lithologic units. Pore fluids have different densities and velocities resulting in the possibility of measuring seismic signature changes when one pore fluid is substituted for another (i.e., water for oil). This study examines the modelled time dependant changes that oil 
depletion has on seismic signature in the $\mathrm{Q}$ fault block of the Hibernia Reservoir.

Computer models were constructed to represent the preproduction reservoir conditions, and then were simulated to account for hydrocarbon depletion and migration as production time is increased. By modelling the response of the reservoir, we can determine a set of elastic parameters that will give us insight as to the changes that we might expect in seismic signature. Changes to the seismic signature will largely be dependent on changes in oil saturation and fluid pressure. These observations will allow us to model the heterogeneity (oil, water contrast) in the subsurface.

By observing changes in the seismic signature, we can gain more knowledge about subsurface fluid flow paths, and subsequently improve reservoir planning to maximize recovery of the resource. These computational models give the Hibernia Management and Development Company insight as to the parameters that would be required for potential 4-D (time dependent) seismic acquisition in the Hibernia Reservoir. 